\title{
Response to the misguided statistical advice regarding aurochs by Bańbura (1992)
}

\author{
Alicja LASOTA-MOSKALEWSKA and Henryk KOBRYŃ
}

\begin{abstract}
Lasota-Moskalewska A. and Kobryń H. 1992. Response to the misguided statistical advice regarding aurochs by Bańbura (1992). Acta theriol. 37: $204-208$.

Discussed aurochs remains consisted of fragments of various bones originating from various individuals. Only a few intact metapodial bones were included into material. Calculated correlation coefficients of the measurements of cattle metapodial bones indicate either lack of correlation or very low correlation between length of bones and breadth of epiphyses. Thus, sugestion by Bańbura (1992) that the previously presented results were significantly influenced by dependence of analised characteristics is unjustified.

Institute of Archaeology, Warsaw University, Żwirki i Wigury 97/99, 02-089 Warsaw, Poland (AL-M); Department of Animal Anatomy, Warsaw Agricultural University, Nowoursynowska 166, 02-766 Warsaw, Poland (HK)
\end{abstract}

Key words: aurochs, archaeozoological remains, contingency table, correlation coefficient

\section{Introduction}

Osteological material gathered from archaeological digs has its own distinct qualities. It is usually broken into small pieces when dividing the carcass. These are scraps left by people most often after the consumption of meat. After being thrown away, these bones laid on the ground and were damaged by mechanical, atmospheric, chemical and biological factors. Then, when they became covered by earth, damaging factors were still at work for hundreds and thousands of years. Sometimes entire epiphyses are unearthed and these can be measured. Intact bones are seldom found, practically only from these parts of a carcass not fit for consumption.

Bone preservation is described in all papers on the subject from which we gleaned osteometric data (for references see Kobryń and Lasota-Moskalewska, 1989). In synthetic works, we do not describe material preservation, as this seems obvious.

Can bone fragments unearthed from digs be representative of a population of animals living on a certain terrain in a particular time? We do not know and never will be able to know for certain. One thing that we do know is that our material has been granted us by fate. Only one factor can help reduce the multitude of possible descriptions - a large sample size. 


\section{Data treatment}

The measurement data used in our work for description of a single bone treated as a skeletal element come from many different bones. Our basic material are single dimensions of bone fragments. In our paper (Lasota-Moskalewska and Kobryń 1990) this is not stated expressis verbis, but the different number of various dimensions regarding a single bone testify to this. In our material only 3 or 4 dimensions per bone taken from about 15 whole metapodial bones and pha- langes were used. These characteristics may be correlated, however, the correl- ation is rather weak. Calkin (1956) calculated the linear correlation coefficients for the cattle metapodial. They are for the maximal length and the breadth of the distal end in metacarpus: $r=0.312(\mathrm{n}=571)$ and in metatarsus: $r=0.269(\mathrm{n}=388)$; for the maximal lenght and breadth of diaphysis in metacarpus: $r=0.354$ $(\mathrm{n}=585)$ and in metatarsus: $r=0.404(\mathrm{n}=394)$. Calkin (1956) concludes that predicting the length of bones on the basis of the breath of the epiphysis results in a wide margin of error. It is known that epiphysis breath is more changable than the diaphysis and that the breath of the proximal epiphysis is more changable than the distal in the aurochs (Bökönyi 1972).
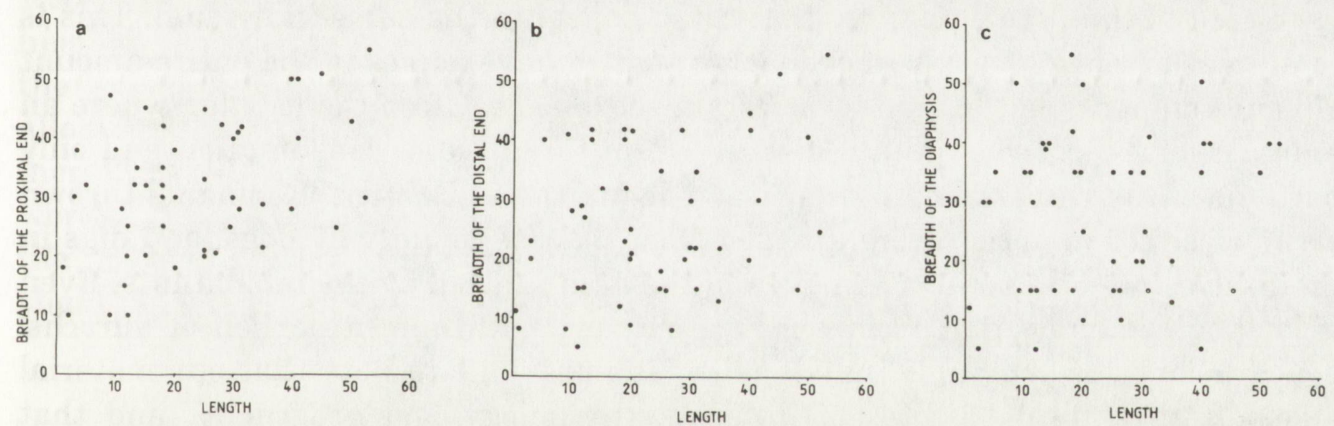

Fig. $1 \mathrm{a}-\mathrm{c}$. Correlation plot between length of metacarpal bone III + IV and breadth of the (a) proximal end $(r=0.423 ; p>0.01)$, (b) distal end $(r=0.244 ; p<0.05)$, (c) diaphysis $(r=0.115$; $p<0.05$ ); $\mathrm{n}=49$. Direct measurements were transformed into points of the point score scale (LasotaMoskalewska 1984).

Transformation of direct measurements into points of the point score scale (Lasota-Moskalewska 1984) enables estimation of a measurement in relation to the maximal distribution of the characteristic. There is no reason to assume that correlation of transformed measurements is stronger than in the case of direct measurements. It is erident, for example from the correlation plot of the transformed measurements of metacarpal bones III + IV of mediaeval domestic cattle from Pułtusk and Płock (Fig. $1 \mathrm{a}-\mathrm{c}$ ). Dispersion of points is very large and correlation coefficients $(r)$ are even lower than those calculated by Calkin (1956). Only the correlation coefficient between length of bones and the breadth of the 
proximal end is significantly different from 0 . Unfortunately, the number of measurements of aurochs bones recorded in the world literature (see LasotaMoskalewska and Kobryń 1990) is too small for plot construction.

In summary, we believe that in our material the number of correlated characteristics taken from intact bones was very small, and that this rather weak correlation could not result in significant multiplication of effects found in our work (Lasota-Moskalewska and Kobryń 1990).

Bańbura (1992) suggests that the bone dimensions used in our work to a great extent come from the same individuals. This could happen only if the material originated from the animal burial grounds. In our material only a single female skeleton from Sweden was present. The dimensions of this skeleton were given in the discussed paper for comparative purposes but were not included in our interpretation of the investigated material (cf. p. 93 in Lasota-Moskalewska and Kobryn 1990). In the case of material from a settlement, where animal remnants are kitchen scraps, it cannot be stated that specific bones come from the same individual. In our practice we often try to calculate the minimum number of individuals of a particular species. We then investigate all analogous preserved epiphyses, dividing them into right and left and according to age and size. It is very rare to find two epiphyses that could belong to the same individual. This is to a great extent due to the fact that we seldom have access to the entire amount of bone remnants left behind by a certain settlement. Often the location where an animal was killed was quite a distance from the place of consumption and only portions of the carcass found their way back to the settlement. Remnants thrown away after consumption were dragged from the site, mainly by dogs, and digs in themselves are often only a fragment of the area utilized by the inhabitants. Even if it should happen that from a single archaeological site a portion of aurochs' bones belongs to the same individual, it is important to note that our material stems from a total 63 sites of differing chronology and geography, and that therefore the individual differences must be large.

The example regarding metric characteristics of a Microtus oeconomus skull cited by Bańbura (1992) has absolutely nothing to do with the material which formed the basis of our work. On a Microtus oeconomus skull one would indeed expect to find a correlation between metric characteristics as they come from the same individual. Cranial characteristics exhibit considerably greater correlation than found in postcranial skeleton. The metric characteristics of bones from dig sites should, to a great degree, be treated independently and that is how we approached them in our work.

If the results we obtained were the effect of erroneous links between dimensions this effect would appear to the same extent in males and females and in both extremities. The fact that we obtained different results for sex and for extremities is the best proof that our assumptions regarding independence were correct. 


\section{Tests}

The significance of surpluses or deficiencies in particular bones in the contingency table was tested with the $\Psi$ test (Góralski 1966). This test is described in a statistics textbook (Góralski 1987). For the reader not familiar with the Polish language, a detailed description of this test along with its possible applications has been published in English (Lasota-Moskalewska and Sulgostowska 1977). In the bibliography of the discussed paper, we listed the first publication of test $\Psi$. In spite of what Bańbura (1992) suggests, test $\Psi$ can be applied independently of results of $\chi^{2}$ test for the entire table. This is because test $\Psi$ belongs to precise tests, in contrast to $\chi^{2}$ test which belongs to the group of approximate tests (personal information from professor Góralski).

Bańbura (1992) advises the use of tests estimating the differences between arithmetic means, for example, the Student $t$-test. If this test were useful for our material, we would use it without encouragement. Student test investigates the difference between two arithmetic means for one characteristic. In our material, the number of occurences for many characteristics was small when segregated by sex, chronology and geography (see Table 14, p. 98 in Lasota-Moskalewska and Kobryń 1990). With these figures only as considerable difference as between the height of aurochs and goats would be correctly analised, as it is well known that the Student $t$-test relies heavily on a number of samples. The method we chose allowed us to consider many characteristics simultaneously, which considerably increased the material and allowed observations of the described tendencies. It is worth adding that we did not compare middle-sized aurochs from the West and the East, but only the share of characteristics with small dimnensions and the share of characteristics with large dimensions.

\section{Presentation}

Table titles with the results of test $\Psi$ are not misleading, as Bańbura (1992) suggests. These tables represent abbreviated and often encountered in the literature form of the contingency table. Detailed results of $\chi^{2}$ test were omitted for editorial reasons. Information as to whether the results of the test are significant or not is provided for each table. If the reader questions the reliability of the authors, it is easy to calculate the value from data contained in columns $\mathrm{n}-\hat{\mathrm{n}}$ and $\hat{\mathrm{n}}$ on the basis of the abbreviated table (cf. Lasota-Moskalewska and Kobryń 1990, p $94-96$ and 99 - 102).

\section{Conclusions}

From the statistical point of view archaeozoological material is different from the contemporary samples. It is not known if it is a random sample and to what 
extent it represents the entire population. It is known, however, that investigation of such material is the only method available to further our knowledge of a species' history.

The particularity of archaeological material allows for the assumption that gathered dimensions come from different individuals and from different bones. We therefore see no reason to change our statistical methods or to hold our results in doubt.

Acknowledgement: We are indebted to professor Andrzej Gorralski for his counsel regarding the contingency table and test $\Psi$.

\section{References}

Bańbura J. 1992. An incorrect analysis of archaeozoological data on the aurochs. Acta theriol. 37: $199-203$.

Bökönyi S. 1972. Aurochs (Bos primigenius Boj.) remains from the Örjeg Peat-bogs between the Danube and Tisza Rivers. Cumania, Archeol. 1: 17 - 56.

Calkin V. J. 1956. Materialy dla istorii skotovodstva i ochoty drevnej Rusi. Mat. i Issled. po Archeol. SSSR. 51: $1-183$.

Góralski A. 1966. Kryterium $\Psi$ oceny istotności nadwyżki i niedoboru liczebności w elementarnej kostce wielodzielczej m-wymiarowej tablicy. Zesz. nauk. Politech. warsz. 131, Mat. 7: 7 - 32.

Goralski A. 1987. Metody opisu i wnioskowania statystycznego w psychologii i pedagogice. Polish Sci. Publ., Warszawa: $1-355$.

Kobryń H. and Lasota-Moskalewska A. 1989. Certain differences between the aurochs and domestic cattle. Acta theriol. 34: $67-82$.

Lasota-Moskalewska A. 1984. The skeleton of prehistoric cow with characteristic of both Promigenious and Brachycerous cattle. Ossa 9/11: $53-72$.

Lasota-Moskalewska A. and Kobryń H. 1990. The size of aurochs skeletons from Europe and Asia in the period from the Neolithic to the Middle Ages. Acta theriol. 35: 89 - 109.

Lasota-Moskalewska A. and Sulgostowska Z. 1977. The application of contingency table for comparison of archaeozoological materials. Ossa 3/4: $153-169$.

Received 19 May 1992. 